\title{
Correction to: Winter home range and habitat selection differs among breeding populations of herring gulls in eastern North America
}

Christine M. Anderson ${ }^{1 *}$, H. Grant Gilchrist ${ }^{2}$, Robert A. Ronconi ${ }^{3}$, Katherine R. Shlepr ${ }^{4}$, Daniel E. Clark ${ }^{5}$, D. V. Chip Weseloh ${ }^{6}$, Gregory J. Robertson ${ }^{7}$ and Mark L. Mallory ${ }^{1}$

\section{Correction to: Mov Ecol}

https://doi.org/10.1186/s40462-019-0152-x

Following publication of the original article [1], the authors reported that one of the authors' names was spelled incorrectly. In this Correction the incorrect and correct author name are shown. The original publication of this article has been corrected.

Originally the author name was published as:

- Gregory J. Roberston

The correct author name is:

- Gregory J. Robertson

\section{Author details}

'Department of Biology, Acadia University, 33 Westwood Ave, Wolfville, NS B4P 2R6, Canada. 'Wildlife Research Division, Environment and Climate Change Canada, National Wildlife Research Centre, Ottawa, ON K1S 5B6, Canada. ${ }^{3}$ Canadian Wild life Service, Environment and Climate Change Canada, 45 Alderney Dr, Dartmouth, NS B2Y 2N6, Canada. ${ }^{4}$ Atlantic Lab for Avian Research, Department of Biology, University of New Brunswick, 10 Bailey Drive, P.O. Box 4400, Fredericton, NB E3B 5A3, Canada. ${ }^{5}$ Massachusetts Department of Conservation and Recreation, Division of Water Supply Protection, 485 Ware Road, Belchertown, MA 01007, USA. ${ }^{6}$ Canadian Wildlife Service, Environment and Climate Change Canada, 4905 Dufferin Ave, Toronto, ON M3H 5T4, Canada. 'Wildlife Research Division, Environment and Climate Change Canada, 6 Bruce Street, Mount Pearl, NL A1N 4T3, Canada.
Received: 25 March 2019 Accepted: 25 March 2019

Published online: 12 April 2019

\section{Reference}

1. Anderson et al. Winter home range and habitat selection differs among breeding populations of herring gulls in eastern North America. Mov Ecol (2019) 7:8 https://doi.org/10.1186/s40462-019-0152-x

\footnotetext{
* Correspondence: christineanderson@acadiau.ca

'Department of Biology, Acadia University, 33 Westwood Ave, Wolfville, NS B4P 2R6, Canada

Full list of author information is available at the end of the article
}

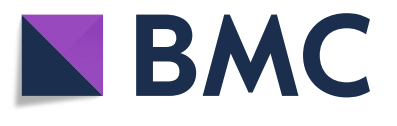

(c) The Author(s). 2019 Open Access This article is distributed under the terms of the Creative Commons Attribution 4.0 International License (http://creativecommons.org/licenses/by/4.0/), which permits unrestricted use, distribution, and reproduction in any medium, provided you give appropriate credit to the original author(s) and the source, provide a link to the Creative Commons license, and indicate if changes were made. The Creative Commons Public Domain Dedication waiver (http://creativecommons.org/publicdomain/zero/1.0/) applies to the data made available in this article, unless otherwise stated. 